\section{Photophysical and biological investigation of novel luminescent Ru(II)-polypyridyl-1,8-naphthalimide Tröger's bases as cellular imaging agents $\dagger$}

\author{
Robert B. P. Elmes, ${ }^{a c}$ Marialuisa Erby, ${ }^{b c}$ Sandra A. Bright, ${ }^{b c}$ D. Clive Williams* ${ }^{* b c}$ and \\ Thorfinnur Gunnlaugsson*ac
}

Received 22nd November 2011, Accepted 13th January 2012

DOI: $10.1039 / \mathrm{c} 2 \mathrm{cc17274g}$

The synthesis and photophysical properties of 1 and 2 , two Ru(II)-polypyridyl based-1,8-naphthalimide Tröger's bases, are described; these were found to stabilize double stranded DNA, undergo rapid cellular uptake, displaying good luminescence without affecting cell viability even after 24 hours of incubation.

Tröger's base was first discovered in 1887, formed upon reaction of para-toluidine with formaldehyde under acidic conditions. ${ }^{1}$ This is a unique structural unit possessing a $C_{2}$ axis of symmetry, as well as being chiral due to two bridgehead stereogenic nitrogen atoms. Formed as a racemic mixture, it is highly strained, where the two aryl groups are close to being orthogonal to each other. ${ }^{2,3}$ Because of this, Tröger's bases have a 'cleft-like" structure, which have found their use in supramolecular chemistry; ${ }^{4-6}$ where they have been employed as a structural scaffold for the formation of metallo-cages, ${ }^{7}$-heterochiral rhombs, ${ }^{8}$ -aggregates, ${ }^{9}$-organic-frameworks (MOFS) ${ }^{10}$ and -helicates. ${ }^{11}$ They have also been used as building blocks in molecular tweezers, ${ }^{12}$ calixarenes, ${ }^{13}$ and various other rigid scaffolds. ${ }^{14}$ Tröger's bases have also been used in the development of novel luminescent materials, ${ }^{15}$ and for probing DNA structure, as we ${ }^{16}$ and others ${ }^{17}$ have demonstrated, but recently, Kirsch-De Mesmaeker et al ${ }^{18}$ formed the first example of Ru(II) polypyridyl complexes of Tröger's bases as potential DNA binders. ${ }^{18}$ Many examples of Ru(II) complexes as DNA targeting binders and as luminescent probes have been developed to date. ${ }^{19}$ These often bind via an intercalation mode, as recently demonstrated by Kelly, Cardin and co-workers, using X-ray crystallography of a $\left[\mathrm{Ru}(\mathrm{TAP})_{2}(\mathrm{dppz})\right]^{2+}$ complex intercalating into an oligonucleotide sequence. ${ }^{20}$ While such complexes have often been shown to have high binding affinity for DNA their potential in vivo has only recently been accessed in any detail. ${ }^{21,22}$ Concomitantly, we have developed many examples of naphthalimide based supramolecular structures, ${ }^{23}$ which absorb and emit within the visible regions, and we have shown that these can be conjugated as antennae

\footnotetext{
${ }^{a}$ School of Chemistry, Centre for Synthesis and Chemical Biology, Trinity College Dublin, Dublin 2, Ireland.E-mail: gunnlaut@tcd.ie; Fax: + 353 1671 2826; Tel: + 35318963459

${ }^{b}$ School of Biochemistry and Immunology, Trinity College, Dublin 2, Ireland.E-mail: clive.williams@tcd.ie

${ }^{c}$ Trinity College Biomedical Sciences Institute, Dublin 2, Ireland

$\dagger$ Electronic supplementary information (ESI) available: Synthesis, 22 figures and 2 tables. See DOI: 10.1039/c2cc17274g
}

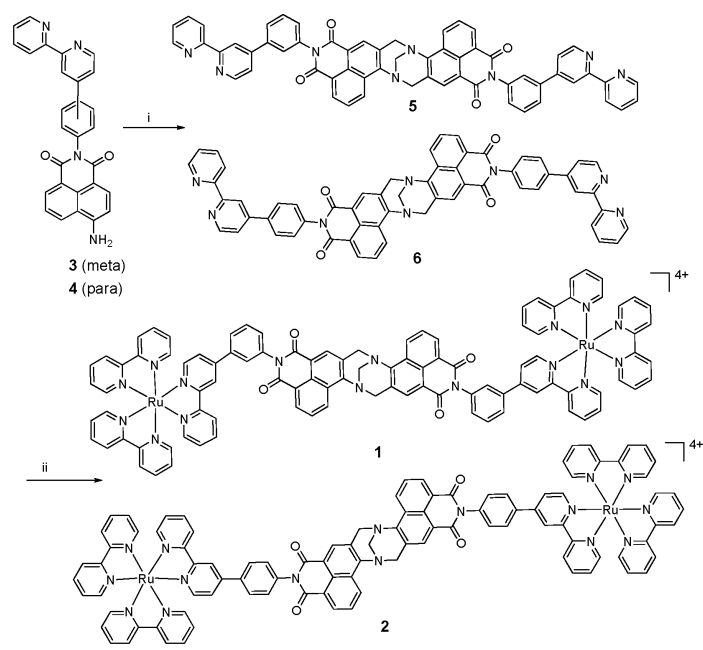

Scheme 1 The synthesis of the bis-Ru(II)polypyridyl naphthalimide complexes 1 and 2. (i) Paraformaldehyde, TFA. (ii) $\mathrm{Ru}(\mathrm{bpy})_{2} \mathrm{Cl}_{2}$, DMSO $/ \mathrm{H}_{2} \mathrm{O}$, microwave irradiation (See full experimental details in $\mathrm{ESI} \dagger$ ).

to $\mathrm{Ru}(\mathrm{II})$ polypyridyl complexes. ${ }^{19 d}$ Herein we present the synthesis and photophysical, cellular uptake and toxicity studies of two novel bis-Ru(III)(bpy) ${ }_{3}$ Tröger's bases, 1 and 2, Scheme 1, derived from the 4-amino-1,8-naphthalimides $\mathbf{3}$ and $\mathbf{4}$, and we demonstrate their application as MLCT luminescent cellular imaging agents. ${ }^{19 a, 21,22}$

The synthesis of $\mathbf{1}$ and $\mathbf{2}$ was achieved in two steps from 3 and $\mathbf{4}$, respectively, in an identical manner (the synthesis of 4 has previously been reported by us ${ }^{19 d}$ ) and 3 was formed similarly (see ESI $\dagger$ ). After reacting 3 with 1.5 equivalents of formaldehyde in neat TFA for 12 hours at room temperature, the reaction mixture was treated with $6 \mathrm{M} \mathrm{NaOH}$ solution, which resulted in the formation of a yellow precipitate. This solid was further purified by precipitation from DMSO solution upon addition of $\mathrm{MeOH}$, giving Tröger's base $\mathbf{5}$ in $68 \%$ yield as a racemic mixture. In an identical manner, the reaction of 4 gave $\mathbf{6}$ in $70 \%$ yield. Both compounds were fully characterised (see full detail in ESI $\dagger$ ). The reaction of 5 with $\mathrm{Ru}(\text { bpy })_{2} \mathrm{Cl}_{2}$, in a mixture of $\mathrm{DMF} / \mathrm{H}_{2} \mathrm{O}(50: 50)$ at $140{ }^{\circ} \mathrm{C}$, using a microwave-assisted synthesis, for 40 minutes, resulted in the formation of an orange coloured solution, from which the $\mathrm{PF}_{6}$ salt of 1 was isolated by precipitation from $\mathrm{H}_{2} \mathrm{O}$ using $\mathrm{NH}_{4} \mathrm{PF}_{6}$. Recrystallization by diethyl-ether diffusion into a $\mathrm{CH}_{3} \mathrm{CN}$ solution gave 1 as a deep-red solid in $68 \%$, while 2 was formed 
in $63 \%$ yield using an identical procedure. Both complexes were characterised using conventional methods (see ESI $\dagger$ ).

Being synthesised as their chloride salts (stirring in Amberlite Cl-form), both $\mathbf{1}$ and $\mathbf{2}$ were fully water-soluble, and as such all photophysical analyses were carried out in $\mathrm{pH} 7.4$ (phosphate) buffered solutions (the photophysical analyses of the precursors 5 and $\mathbf{6}$ were carried out in $\mathrm{CH}_{2} \mathrm{Cl}_{2}$, see ESI $\dagger$ for full details). The UV-Vis absorption spectrum of $\mathbf{1}$ is shown in Fig. 1, being similar to 2 (ESI $\dagger$ ), consisting of two bands at $240 \mathrm{~nm}$ and $290 \mathrm{~nm}$ while the absorption region between $350 \mathrm{~nm}$ and $500 \mathrm{~nm}$ is composed of a single broad absorption band composed of maxima at $350 \mathrm{~nm}, 400 \mathrm{~nm}, 430 \mathrm{~nm}$ and $460 \mathrm{~nm}$. The bands at $240 \mathrm{~nm}$ and $290 \mathrm{~nm}$ are characteristic of $\pi-\pi^{*}$ intra-ligand transitions within the bipyridine ligands while the less intense bands between $350 \mathrm{~nm}$ and $500 \mathrm{~nm}$ are attributed to the combination of ICT transitions within the naphthalimide portion of $\mathbf{1}$ and 2, and the MLCT transitions associated with the Ru(II) centres at $430 \mathrm{~nm}$ and $460 \mathrm{~nm}$. Excitation into all of the aforementioned absorption bands of $\mathbf{1}$ and $\mathbf{2}$ resulted in the appearance of ${ }^{3}$ MLCT based emission centred at $c a .615 \mathrm{~nm}$; the absence of any 1,8-naphthalimide associated emission suggesting that sensitisation of the MLCT excited state occurs through some mixing of low-lying isoenergetic triplet states, ${ }^{3} \mathrm{MLCT}$ and ${ }^{3} \mathrm{Nap}$, as described by Castellano et al. ${ }^{24}$ as the ICT emission centred at $505 \mathrm{~nm}$ overlaps with the ${ }^{1}$ MLCT absorption of the Ru(II) centre. Similarly, the fluorescence quantum yields measured for $\mathbf{1}$ and $\mathbf{2}$ were found to be identical with $\Phi_{\mathrm{MLCT}}=0.015( \pm 10 \%)$ but significantly lower than that measured for the parent $\left[\mathrm{Ru}(\mathrm{bpy})_{3}\right]^{2+}\left(\Phi_{\mathrm{MLCT}}=0.028\right)$ again suggesting an interaction between the 1,8-naphthalimide and the ${ }^{3}$ MLCT triplet state of the Ru(II) centres. Excited state lifetime measurements $\left(\tau_{\mathrm{em}}\right)$ were also obtained in with $\tau_{\mathrm{em}}=187 \mathrm{~ns}$ and 174 ns for 1 and 2, respectively; indicating similar photophysical behaviour.

As has been observed in the study reported by Veale et al. ${ }^{16}$ significant modulations of the photophysical characteristics of Tröger's base analogues have been observed upon interaction with DNA suggesting a strong binding affinity of these structures for the DNA biomolecule. With the inclusion of the cationic $\mathrm{Ru}(\mathrm{II})$ polypyridyl centres we envisaged that both $\mathbf{1}$ and $\mathbf{2}$ may also bind to DNA and as such, UV/Vis absorption and emission spectroscopy titrations with stDNA were initially carried out to probe this interaction. Surprisingly, only minor

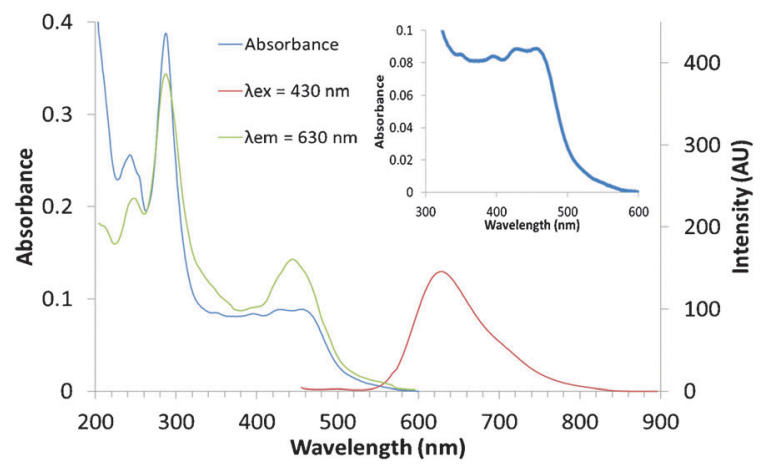

Fig. 1 The UV/Visible absorption, excitation and emission spectra of 1 in $10 \mathrm{mM}$ phosphate buffer at $\mathrm{pH}$ 7.4. Inset: The UV/Vis absorption region between $300 \mathrm{~nm}$ and $600 \mathrm{~nm}$. changes were observed, where in the UV/Vis absorption spectra of 1 , a small red shift coupled with $8 \%$ hypochromism at $400 \mathrm{~nm}$ and $6 \%$ hypochromism at $460 \mathrm{~nm}$ was observed for $P / D 0 \rightarrow 50$ (see ESI $\dagger$ ). For 2 a slightly larger change of $13 \%$ hypochromism at $400 \mathrm{~nm}$, and 10\% hypochromism at $460 \mathrm{~nm}$ was observed (see ESI $\dagger$ ). Similarly, the effect on the luminescence intensity upon the addition of stDNA to solutions of $\mathbf{1}$ and $\mathbf{2}$ over the same range $(P / D 0 \rightarrow 50)$ was minor (see ESI $\dagger)$. In contrast the $\mathrm{Ru}(\mathrm{II})(\mathrm{bpy})_{3}$ complex of $\mathbf{4}$ gave rise to large changes in their absorption and the emission spectra. This clearly demonstrates that the Tröger's base moiety in $\mathbf{1}$ and $\mathbf{2}$ had significant effect on the ability of these structures to bind to DNA in a classical groove or intercalation fashion.

Due to these relatively small spectral changes observed above, we were unable to determine the binding constants from these interactions accurately. Nevertheless, DNA denaturation $\left(T_{\mathrm{m}}\right)$ studies using $\mathbf{1}$ and $\mathbf{2}$ clearly showed significant changes in the melting behaviour of stDNA in the presence of both, see Fig. 2 for $P / D=10$. Hence, while the binding of $\mathbf{1}$ and $\mathbf{2}$ to DNA did not result in any major alternation in their photophysical properties, both were able to stabilize the helical structure of DNA to a large degree. Importantly, for both $P / D$ ratios, 1 was observed to give rise to greater stabilisation over that seen for 2, $c f$. Fig. 2 (and ESI $\dagger$ ). This is most likely due to the structural difference between the two systems, where orientation of the two $\mathrm{Ru}(\mathrm{II})$ centres is with respect to the Tröger's base framework. In order to probe this interaction more thoroughly and to evaluate the role of electrostatic interactions in the binding of $\mathbf{1}$ and $\mathbf{2}$ to DNA, $T_{\mathrm{m}}$ studies were also undertaken at varying concentrations of $\mathrm{NaCl}(25 \mathrm{mM}$ and $50 \mathrm{mM})$. In the absence of $\mathbf{1}$ and $\mathbf{2}$, the $T_{\mathrm{m}}$ for stDNA was determined as $76{ }^{\circ} \mathrm{C}$ in the presence of $25 \mathrm{mM} \mathrm{NaCl}$; but this value was increased significantly in the presence of $\mathbf{1}$ and $\mathbf{2}$, where the melting transition, once more, had not fully completed at $90{ }^{\circ} \mathrm{C}$ for $\mathbf{1}$ (see ESI $\dagger$ ). Similar results were observed for 1, at $50 \mathrm{mM} \mathrm{NaCl}$, while $T_{\mathrm{m}}$ for 2 was shifted to $82{ }^{\circ} \mathrm{C}$. It is clear from these results that the interaction of $\mathbf{1}$ and $\mathbf{2}$ with DNA is highly dependent on the ionic strength of the medium, and although these interactions play a major role in the binding process, it appears that there are other factors affecting the association of these complexes with DNA.

Because of the minor changes observed in the photophysical properties of $\mathbf{1}$ and $\mathbf{2}$ upon binding to DNA, their potential to act as luminescent cellular probes were next evaluated. Populations of live HeLa cervical cancer cells $\left(1 \times 10^{5}\right)$ were incubated

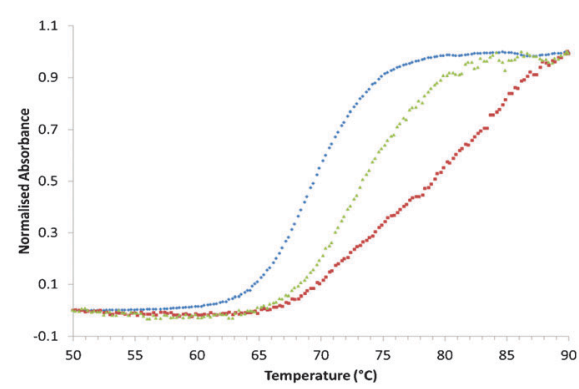

Fig. 2 Thermal denaturation curves of stDNA $(150 \mu \mathrm{M})$ in $10 \mathrm{mM}$ phosphate buffer, pH 7.4, in the absence $(\$)$ and presence of $\mathbf{1}(\square)$ and $2(\Delta)$ at $P / D=10$. 


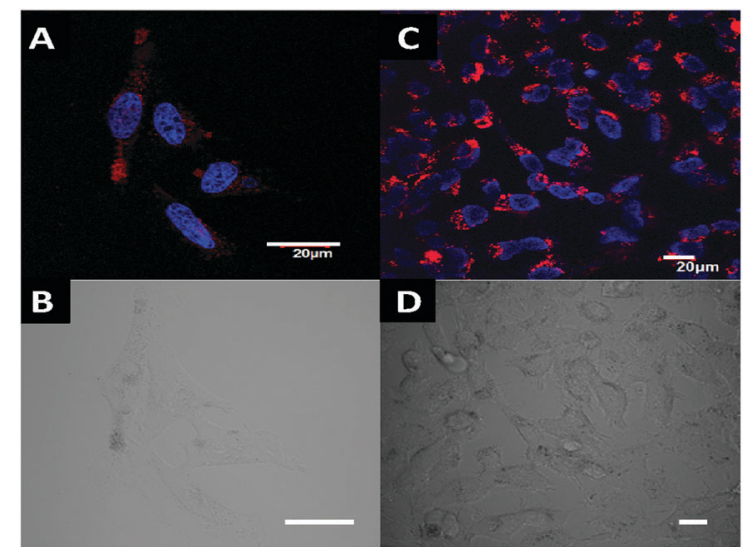

Fig. 3 Confocal laser scanning microscopy live cell images of $\mathbf{1}$ and $\mathbf{2}$ $(10 \mu \mathrm{M})$ (shown as red) within HeLa cells. (A) The emission of $\mathbf{2}$ after 4 hours incubation and stained with DAPI (blue); (B) 2 phase contrast image. (C) The emission of 1 after 24 hours incubation, stained with DAPI (blue); (D) 1 phase contrast image.

with 1 and $2(10 \mu \mathrm{M})$ at $37^{\circ} \mathrm{C}$ for $2,4,8$ and 24 hours' time points before being treated with the fluorescent nuclear stain DAPI and viewed using a confocal fluorescence scanning microscope. Fig. 3 shows representative microscopy pictures after incubation with $\mathbf{1}$ and $\mathbf{2}$ at various time points. Both complexes, being red emitting, were highly fluorescent upon excitation at 488 , and are clearly visible within the cells even after 2 hours of treatment. Imaging of cells treated with either $\mathbf{1}$ or $\mathbf{2}$ for 4, 8 and 24 hours demonstrates complete uptake within 4 hours (see ESI $\dagger$ ). The images showed that both compounds localise mainly within the cytoplasm or to the edge of the nucleus with some cells exhibiting fluorescence from within the cell nucleus. Testing with a large range of concentrations $(0.5 \rightarrow 15 \mu \mathrm{M})$ of $\mathbf{1}$ and $\mathbf{2}$ in HeLa cells, the alamar blue viability assay demonstrated no concentration dependent effects on cell viability including no cytotoxic or proliferative effects on the cells (see ESI $\dagger$ ). Moreover, $\mathrm{EC}_{50}$ values could not be determined for either of these complexes. Hence, $\mathbf{1}$ and $\mathbf{2}$ exhibit good behaviour as cellular imaging agents, the application of which we are currently investigating in greater detail. However, compound $\mathbf{1}$ was shown to give rise to some membrane blebbing (see ESI $\dagger$ ) in comparison to $\mathbf{2}$, hence we are currently focusing our efforts on studying $\mathbf{1}$ as an imaging and potential therapeutic agent.

In summary we have developed novel bis-Ru(II)(bpy) ${ }_{3}$ Tröger's bases $\mathbf{1}$ and 2, which have been found to bind to DNA and undergo rapid cellular uptake, being internalised after just 2 hours and highly fluorescent while displaying no effects on cellular viability.

We thank Science Foundation Ireland (SFI RFP 2009 and SFI 2010 PI awards), HEA PRTLI Cycle 4, The Irish Research Council for Science, Engineering and Technology (IRCSET Postgraduate Studentship to RPBE) and PROGRAMMA MASTER AND BACK - Regione Autonoma della Sardegna-2009-Alta formazione (ME) for financial support. We also thank Dr Susan J. Quinn and Dr Emma B. Veale for their helpful discussion.

\section{Notes and references}

1 J. J. Tröger, Prakt. Chem., 1887, 36, 225.

2 (a) S. Sergeyev, Helv. Chim. Acta, 2009, 92, 415; (b) B. Dolensky, J. Elguero, V. Kral, C. Pardo and M. Valik, Adv. Heterocycl. Chem., 2007, 93, 1.
3 (a) M. Valik, R. M. Strongin and V. Král, Supramol. Chem., 2005, 17, 347; (b) B. G. Bag, Curr. Sci., 1995, 68, 279.

4 C. S. Wilcox and M. D. Cowart, Tetrahedron Lett., 1986, 27, 5563.

5 (a) E. Kim, S. Paliwal and C. S. Wilcox, J. Am. Chem. Soc., 1998, 120, 11192; (b) S. H. Wilen, J. Z. Qi and P. G. Williard, J. Org. Chem., 1991, 56, 485; (c) M. J. Crossley, L. J. MacKay and A. C. Try, J. Chem. Soc., Chem. Commun., 1995, 1925; (d) S. Goswami, K. Ghosha and S. Dasgupta, J. Org. Chem., 2000, 65, 1907.

6 N. Dalla Favera, U. Kiehne, J. Bunzen, S. Hytteballe, A. Lutzen and C. Piguet, Angew. Chem., Int. Ed., 2010, 49, 125.

7 A. C. Arribas, O. F. Wendt, A. P. Sundin, C. J. Carling, R. Y. Wang, R. P. Lemieux and K. Warnmark, Chem. Commun., 2010, 46, 4381.

8 T. Weilandt, U. Kiehne, G. Schnakenburg and A. Lutzen, Chem. Commun., 2009, 45, 2320.

9 T. Weilandt, U. Kiehne, J. Bunzen, G. Schnakenburg and A. Lutzen, Chem.-Eur. J., 2010, 16, 2418.

10 Y. M. Jeon, G. S. Armatas, D. Kim, M. G. Kanatzidis and C. A. Mirkin, Small, 2009, 5, 46.

11 (a) U. Kiehne, T. Weilandt and A. Lutzen, Eur. J. Org. Chem., 2008, 2056; (b) U. Kiehne, T. Weilandt and A. Lutzen, Org. Lett., 2007, 9, 1283.

12 (a) M. Havlik, V. Král, R. Kaplanek and B. Dolensky, Org. Lett., 2009, 10, 4767; (b) C. S. Wilcox and M. D. Cowart, Tetrahedron Lett., 1986, 27, 5563.

13 M. Valik, J. Cejka, M. Havlik, V. Kral and B. Dolensky, Chem. Commun., 2007, 3835.

14 (a) S. P. Bew, L. Legentil, V. Scholier and S. V. Sharma, Chem. Commun., 2007, 389; (b) P. R. Brotherhood, R. A. S. Wu, P. Turner and M. J. Crossley, Chem. Commun., 2007, 225.

15 C. X. Yuan, X. T. Tao, L. Wang, J. X. Yang and M. H. Jiang, J. Phys. Chem. C, 2009, 113, 6809; G. Brown and D. E. Lewis, Tetrahedron Lett., 2005, 46, 2149.

16 (a) E. B. Veale and T. Gunnlaugsson, J. Org. Chem., 2010, 75, 5513; (b) E. B. Veale, D. O. Frimannsson, M. Lawler and T. Gunnlaugsson, Org. Lett., 2009, 11, 4040.

17 (a) M. Valík, J. Malina, L. Palivec, J. Foltýnová, M. Tkadlecová, M. Urbanová, V. Brabec and V. Král, Tetrahedron, 2006, 62, 8591; (b) C. Bailly, W. Laine, M. Demeunynck and J. Lhomme, Biochem. Biophys. Res. Commun., 2000, 273, 681; (c) A. Tatibouet, M. Demeunynck, C. Andraud, A. Collet and J. Lhomme, Chem. Commun., 1999, 161; (d) E. Yashima, M. Akashi and N. Miyauchi, Chem. Lett., 1991, 1017.

18 (a) N. Claessens, F. Pierard, C. Bresson, C. Moucheron and A. Kirsch-De Mesmaeker, J. Inorg. Biochem., 2007, 101, 987; (b) O. Van Gijte, A. Tatibouet, M. Demeunynck, J. Lhomme and A. Kirsch-De Mesmaeker, Tetrahedron Lett., 1997, 38, 1567.

19 (a) R. B. P. Elmes, K. N. Orange, S. M. Cloonan, D. C. Williams and T. Gunnlaugsson, J. Am. Chem. Soc., 2011, 133, 15862; (b) S. Vasudevan, J. A. Smith, M. Wojdyla, T. McCabe, N. C. Fletcher, S. J. Quinn and J. M. Kelly, Dalton Trans., 2010, 39, 3990; (c) B. Elias, C. Creely, G. W. Doorley, M. M. Feeney, C. Moucheron, A. Kirsch-DeMesmaeker, J. Dyer, D. C. Grills, M. W. George, P. Matousek, A. W. Parker, M. Towrie and J. M. Kelly, Chem.-Eur., J., 2008, 14, 369; (d) G. J. Ryan, S. J. Quinn and T. Gunnlaugsson, Inorg. Chem., 2008, 47, 401; (e) A. M. Nonat, S. J. Quinn and T. Gunnlaugsson, Inorg. Chem., 2009, 48, 4646; (f) R. B. P. Elmes and T. Gunnlaugsson, Tetrahedron Lett., 2010, 51, 4082.

20 J. P. Hall, K. O'Sullivan, A. Naseer, J. A. Smith, J. M. Kelly and C. J. Cardin, Proc. Natl. Acad. Sci. U. S. A., 2011, 43, 17610.

21 (a) V. Fernanderz-Moreira, F. L. Thorp-Greenwoood and M. P. Coogan, Chem. Commun., 2010, 46, 186; (b) C. A. Puckett, R. J. Ernst and J. K. Barton, Dalton. Trans., 2010, 39, 1159.

22 (a) M. R. Gill, J. Garcia-Lara, S. J. Foster, C. Smythe, G. Battaglia and J. A. Thomas, Nat. Chem., 2008, 1, 662; (b) M. R. Gill, H. Derrat, C. G. W. Smythe, G. Battaglia and J. A. Thomas, ChemBioChem, 2011, 12, 877; (c) X. Tian, M. R. Gill, I. Canton, J. A. Thomas and G. Battaglia, ChemBioChem, 2011, 12, 548; (d) U. Neugebauer, Y. Pellegrin, M. Devocelle, R. J. Foster, W. Sigma, N. Moran and T. E. Keyes, Chem. Commun., 2008, 5307.

23 R. M. Duke, E. B. Veale, F. M. Pfeffer, P. E. Kruger and T. Gunnlaugsson, Chem. Soc. Rev., 2010, 39, 3936.

24 D. S. Tyson, C. R. Luman, X. Zhou and F. N. Castellano, Inorg. Chem., 2001, 40, 4063. 